\title{
A novel sequential heap leach process for treating crushed Platreef ore
}

\author{
James M. Mwase ${ }^{\dagger 1}$, Jochen Petersen ${ }^{\dagger}$, Jacques J. Eksteen ${ }^{\beta}$ \\ $\dagger$ Centre for Bioprocess Engineering, Department of Chemical Engineering, University of Cape Town, \\ Rondebosch, South Africa \\ ß Department of Metallurgical Engineering, Western Australia School of Mines, Curtin University, GPO Box \\ U1987, Perth, WA 6845, Australia
}

The original version of this article is available in Hydrometallurgy 141 (2014) 97-104

\begin{abstract}
A novel sequential heap leaching process has been identified as a possible alternative to the conventional concentrate-smelt-refine route for processing Platreef ore, a platinum group metals containing ore with palladium predominance. The present study focuses on testing this process on crushed whole ore, after initial experiments conducted on low-grade Platreef flotation concentrate achieved promising results. Two samples of drill core Platreef ore with size distributions of $-25 \mathrm{~mm}+1 \mathrm{~mm}$ and $-6 \mathrm{~mm}+1 \mathrm{~mm}$ were first bioleached in cylindrical columns, to simulate heap leaching, at $65^{\circ} \mathrm{C}$ and then leached with cyanide solution at $50^{\circ} \mathrm{C}$ in cylindrical columns. Overall the best results were achieved from the tests on the $-6 \mathrm{~mm}+1 \mathrm{~mm}$ size fraction sample. After 304 days $93 \% \mathrm{Cu}, 75 \% \mathrm{Ni}$ and $53 \%$ Co were extracted in the bioleach experiment, and after 60 days $57.8 \% \mathrm{Pt}, 99.7 \% \mathrm{Pd}$ and $90.3 \% \mathrm{Au}$ in the follow-up cyanide leach experiment. Analysis using a mineral liberation analyser suggested that $\mathrm{Pt}$ and $\mathrm{Pd}$ were leached mostly from the tellurides while the Pt arsenides appeared resistant to cyanide leaching. From the results it is proposed that the process considered herein is a potential alternative route to treat Platreef ore.
\end{abstract}

Key words: Platinum group metals, heap leaching, bioleaching, cyanide, Platreef ore

\subsection{Introduction}

The Platreef is a largely untapped source of platinum group metals (PGMs) and base metals (BMs) located in the Bushveld Igneous Complex in South Africa. Unlike the Merensky and Upper Group 2 (UG2) ore bodies, there are several factors which make it challenging to exploit this ore body economically via the standard crushing-milling-flotation-smelting-refining method without the benefit of additional ultra fine grinding and blending with higher grade concentrates (Newell, 2008). Chief among these is the poor floatability of the PGMs which are predominantly Pt and Pd tellurides and Pt arsenides, which deport mostly to the silicates rather than sulphides (Shackleton et al., 2007a; Shackleton et al., 2007b). For this reason high mass pulls of around 4-6\% (as compared to the usual 2\%) are required to achieve acceptable grade recoveries of PGMs (Schay, 2009; Mogoseti, 2006). This in turn results in a poor quality concentrate material which cannot feasibly be processed by a PGM smelter. Additionally, the ratio of Pd to Pt is almost 1.2:1 as opposed to Merensky and UG2 reefs where it is 2:1 in favour of Pt (Bushell, 2006). Although certain outcrops of the Platreef allow opencast mining, the rapid dip downwards towards the west from the outcrop necessitates expensive underground mining with backfilling, which adds substantially to operating and capital costs. There is also a high variation in hardness and grade across the reef (Schouwstra and Kinloch, 2000) and for this reason some of the ore may be suitable for milling and smelting, while significant sections do not meet the cut-off grade for the standard process. Platreef ore also contains very little

\footnotetext{
${ }^{1}$ Corresponding author: Tel: +27 21650 3804, Fax: +27 21650 5501, Email: mwsjam001 @ myuct.ac.za
} 
chromite, and the content of Rh, Ir and Ru is much less than that of Merensky or UG2 (Seymour and O'Farrelly, 2001). Furthermore, Platreef deposits are located in an arid area of South Africa, with a low skilled labour pool and poor electrical infrastructure.

This study therefore assesses the possiblity of eliminating the costly concentrator, smelter and pressure leach stages by directly leaching crushed whole ore through a sequential heap leaching process, or running a low-grade heap leach operation parallel with a high grade conventional operation. The first stage of this process involves a thermophile heap bioleach to extract BMs $(\mathrm{Cu}, \mathrm{Ni}$, and $\mathrm{Co})$. Bioleaching is relevant in this context due to the prevalance of BMs as sulphide minerals in the Platreef ore. The pyrite and pyrrhotite provide ferric ions for leaching chalcopyrite and pentlandite and they also facilitate heat generation by sulphide mineral oxidation. The sulphide-sulphur content in the Platreef ore has the potential to allow the process to reach an operating temperature of $60-65^{\circ} \mathrm{C}$ based on comparisons to other whole ore heap leach operations (Tempel, 2003; Ream and Schlitt, 1997) with similar sulphide-sulphur content in the ore. These elevated temperatures can be successfully maintained in the heap by manipulation of solution irrigation and aeration rates to the heap, as successfully demonstrated in the Sarcheshmeh chalcopyrite heap bioleaching operation in Iran (Neale, 2012; Pradhan et al., 2008). The elevated temperatures not only facilitate faster reaction kinetics, but enable the leaching of $\mathrm{Cu}$ from the chalcopyrite, which would otherwise not leach at temperatures below $50^{\circ} \mathrm{C}$. This process is followed by heap reclamation, a water wash step and re-stacking of the heap onto a new pad for a high temperature cyanide leach, achieved via solar heating of solution, to extract precious metals (Pt, Pd and Au) (Eksteen et al., 2012). Additionally, it is proposed that solar heating should be used to heat up the wash water used between the two stages. Washing the residual ore with heated water may help retain most of the heat generated during the exothermic bioleach stage within the ore, when it is moved to the cyanide leaching stage. Separate test work has shown that the BMs can be recovered from the bioleach pregnant solution using ion exchange resins and subsequent elution (Liebenberg et al., 2013). Alternatively, these metal values can also be recovered using conventional methods, such as a solvent extraction-electrowinning circuit (Jergensen, 1999; Gupta and Mukherjee, 1990) or via sulphide precipitation (Riekkola-Vanhanen, 2010). Similarly, test work has also shown that the precious metals can be recovered from the pregnant cyanide solutions using either adsorption to resins or activated carbon and subsequent elution (Schoeman et al., 2012; Snyders et al., 2013).

The current work is a continuation of the evaluation of the novel sequential heap leaching process to treat Platreef ore. In the first phase of this study, test work was conducted on lowgrade Platreef concentrate which served as a proxy material (Mwase et al., 2012a). This was done to facilitate a faster turn around of results and to establish optimal conditions for operating before proceeding to test the process on coarse ore. In the first stage, a bioleach process using thermophiles, specifically Metallosphaera hakonensis, was applied to samples of concentrate coated onto inert support. Metallosphaera hakonensis was chosen because it can efficiently oxidize both iron and sulphur at elevated temperatures (Plumb et al., 2008). The coated samples were packed in cylindrical columns and irrigated with leach solution to simulate heap leaching. Extractions of up to $91.1 \% \mathrm{Cu}, 98.5 \% \mathrm{Ni}$ and $83.5 \%$ Co were achieved in a space of 88 days at the optimal temperature of $65^{\circ} \mathrm{C}$. The residual concentrate from this experiment was similarly treated via columns in a second stage leach using cyanide solution, achieving extractions of up to $96.5 \% \mathrm{Pd}, 97.5 \% \mathrm{Au}$ and $35 \% \mathrm{Pt}$ in a space of 45 days at $50^{\circ} \mathrm{C}$. However, it was noted that the Pt extraction had not stopped but continued leaching albeit at a significantly reduced rate. Analysis using a mineral liberation analyser (MLA) on the concentrate showed that of the remaining Pt, $78 \%$ was sperrylite $\left(\mathrm{PtAs}_{2}\right)$ and at this point the 
PGMs were $91 \%$ liberated. This suggested that mineralogy was perhaps a limiting factor on the leaching rate of Pt. Another factor that may have also contributed to the low Pt extractions was that the leaching was conducted in what essentially constituents a batch reactor configuration. PLS was recycled for extended periods of time before being exchanged for fresh solution. Given the slow kinetics of $\mathrm{Pt}$ leaching in comparison to $\mathrm{Pd}$ and $\mathrm{Au}$, it was hypothesised that a continuous system, where fresh solution is introduced more frequently, will produce better extractions of Pt.

Additionally, the presence of thiocyanate at high levels was detected in the cyanide effluent solution, indicating the presence of reduced sulphur compounds in the concentrate. MLA analysis of the bioleached residual concentrate indicated the absence of elemental sulphur and only minor traces of sulphide minerals. The remaining sulphide minerals could not account for the total sulphur content indicated by a LECO combustion test on the residual concentrate. This measurement suggested that only $44 \%$ of the original total sulphur in the concentrate had been oxidized in the bioleach process. It is suggested that the discrepancy is due to incomplete sulphur oxidation in the bioleach stage. The sulphur compounds formed are most likely to be polysulphides or polythionates which precipitated to a solid form and migrated with the residual concentrate to the cyanide leach stage (Aswegen et al., 2007). These sulphur species are known to be very reactive with cyanide and form thiocyanate (Luthy and Bruce, 1979), but were not detected during the MLA analysis. In the current test phase on coarse ore particles, it is hypothesised that due to the longer leaching time required for coarse ore, perhaps the problem of incomplete sulphur oxidation will not occur or will at least be minimized, as the bacteria will have a significantly longer time to oxidise both the sulphur and iron., It is further proposed that the high conversion of cyanide to thiocyanate, coupled with leaching of the material in a batch recycle mode, led to insufficient free cyanide to leach the Pt. This situation was exacerbated by the slow leaching kinetics of Pt.

This present study applies the process, with some modifications, to coarse ore particles and focuses on the influence of ore particle size on the performance of the process.

\subsection{Materials}

A bulk sample of Platreef drill core ore, crushed by by high pressure grinding rolls (HPGR) at a pressure of $2.5 \mathrm{~N} / \mathrm{mm}^{2}$, was used for the test work. From this two representative samples, weighing $4 \mathrm{~kg}$ each, were obtained using a 2-way riffle splitter and screened to remove particles below $1 \mathrm{~mm}$. One sample (column 1) had a size distribution of $-25 \mathrm{~mm}+1 \mathrm{~mm}$ and the second (column 2) was screened to a size range of $-6 \mathrm{~mm}+1 \mathrm{~mm}$. The head grades (Table 1 and 2) and bulk mineralogy (Table 3) were obtained through fire assays and MLA analysis of representative sub-samples from the two samples. The results from the MLA also showed the PGMs were predominantly tellurides namely moncheite $\left(\mathrm{PtPd}(\mathrm{BiTe})_{2}\right.$ and $\left.\mathrm{PtTe}_{2}\right)$, merenskyite $\left(\mathrm{PdPt}(\mathrm{BiTe})_{2}\right.$ and $\left.\mathrm{PdTe}_{2}\right)$, maslovite (PtBiTe) and kotulskite [Pd(Te, Bi)] followed by arsenides (mostly sperrylite-PtAs 2 ) with a small amount of sulphides (mostly cooperite-PtS), sulpharsenides and PtFe alloys. The silicates were the most common host minerals for PGMs, and where PGMs were associated with sulphide minerals; pentlandite and pyrrhotite were the most common hosts with chalcopyrite to a lesser extent. 
Table 1: Saleable metals and elements of major influence on leaching process

\begin{tabular}{lllllllllll}
\hline & $\mathbf{P t}$ & $\mathbf{P d}$ & $\mathbf{A u}$ & $\mathbf{R h}$ & $\mathbf{R u}$ & $\mathbf{C u}$ & $\mathbf{N i}$ & $\mathbf{C o}$ & $\mathbf{F e}$ & $\mathbf{S}$ \\
$\mathrm{g} / \mathrm{t}$ & $\mathrm{g} / \mathrm{t}$ & $\mathrm{g} / \mathrm{t}$ & $\mathrm{g} / \mathrm{t}$ & $\mathrm{g} / \mathrm{t}$ & $\%$ & $\%$ & $\mathrm{~g} / \mathrm{t}$ & $\%$ & $\%$ \\
\hline Column 1 & 1.6 & 2.0 & 0.3 & 0.2 & 0.2 & $\mathbf{0 . 1 3}$ & $\mathbf{0 . 3 5}$ & $\mathbf{1 3 0 . 0}$ & 8.6 & 0.8 \\
Column 2 & 1.6 & 2.0 & 0.3 & 0.2 & 0.2 & $\mathbf{0 . 1 2}$ & $\mathbf{0 . 3 5}$ & $\mathbf{1 2 9 . 0}$ & 8.6 & 0.8 \\
\hline
\end{tabular}

Table 2: Major gangue and trace elements

\begin{tabular}{lllllllllllllll}
\hline & $\mathbf{M g}$ & $\mathbf{A l}$ & $\mathbf{C a}$ & $\mathbf{C r}$ & $\mathbf{S i}$ & $\mathbf{M n}$ & $\mathbf{T i}$ & $\mathbf{P b}$ & $\mathbf{V}$ & $\mathbf{Z n}$ & $\mathbf{A s}$ & $\mathbf{S e}$ & $\mathbf{T e}$ & $\mathbf{B i}$ \\
& $\%$ & $\%$ & $\%$ & $\%$ & $\%$ & $\%$ & $\%$ & $\mathrm{~g} / \mathrm{t}$ & $\mathrm{g} / \mathrm{t}$ & $\mathrm{g} / \mathrm{t}$ & $\mathrm{g} / \mathrm{t}$ & $\mathrm{g} / \mathrm{t}$ & $\mathrm{g} / \mathrm{t}$ & $\mathrm{g} / \mathrm{t}$ \\
\hline Column 1 & 14.1 & 2.5 & 4.2 & 0.3 & 23.3 & 0.2 & 0.1 & 19.5 & 93.0 & 33.0 & 3.3 & 1.8 & 4.3 & 0.1 \\
Column 2 & 14.9 & 2.5 & 4.1 & 0.3 & 22.3 & 0.2 & 0.1 & 13.3 & 93.0 & 24.0 & 5.0 & 2.1 & 4.4 & 0.1 \\
\hline
\end{tabular}

Table 3: Bulk mineralogy of Platreef drill core sample

\begin{tabular}{ll}
\hline Mineral & Weight \% \\
\hline Pyrrhotite & 1.8 \\
Pentlandite & 1.7 \\
Chalcopyrite & 0.8 \\
Pyrite & 0.1 \\
Olivine \& Orthopyroxene & 36.0 \\
Serpentine & 22.7 \\
Chlorite & 3.2 \\
Talc & 5.7 \\
Clinopyroxene & 13.0 \\
Magnetite & 6.6 \\
Chromite & 0.8 \\
\hline
\end{tabular}

\subsection{Method}

\subsection{Column bioleaching}

The aim of this experiment was to determine the extent to which BMs could be extracted from Platreef whole ore using a bioleach process that was previously applied, with successful results, to low-grade Platreef flotation concentrate coated onto inert support.

The samples of whole ore were placed in cylindrical PVC columns $10 \mathrm{~cm}$ in diameter and 50 $\mathrm{cm}$ in length (schematic drawing as seen in Mwase et al., 2012b). Initially the samples were treated with a $30 \mathrm{~g} / \mathrm{L} \mathrm{H}_{2} \mathrm{SO}_{4}$ solution, fed into the columns from the top at a rate of $1 \mathrm{~L} /$ day (translated from a typical industrial flow rate of $5 \mathrm{~L} / \mathrm{m}^{2} / \mathrm{h}$ ). This was done for 44 days in order to dissolve as much of the acid soluble BM minerals as possible, and the effluent was collected from the bottom of the column. The feed solution was thereafter replaced with a solution containing $0.5 \mathrm{~g} / \mathrm{L} \mathrm{Fe}$ (as ferrous sulphate) and $10 \mathrm{~g} / \mathrm{L} \mathrm{H}_{2} \mathrm{SO}_{4}$, which was fed into the column at the same rate and in the same manner. The columns were heated to and maintained at $65^{\circ} \mathrm{C}$ using an external heating coil wrapped around the columns. At this point the columns were inoculated with what was essentially a pure culture of Metallosphaera hakonensis which was identified and quantified using quantitative real time polymerase chain reaction (qRT PCR). The columns were aerated at a rate of $130 \mathrm{~mL} / \mathrm{min}$. Samples of solution were collected from the effluent at various intervals for analysis of BMs and gangue elements via inductively 
coupled plasma optical emission spectrometry (ICP-OES). Additionally, the $\mathrm{pH}$ and redox potential were also measured from the samples taken and recorded each time, using a standard $\mathrm{pH}$ meter and $\mathrm{Ag} / \mathrm{AgCl}-\mathrm{Pt}$ combination redox probe, respectively. After 304 days of leaching, the extractions achieved were calculated by averaging the extractions determined from the solution assays and those determined by fire assay of sub-samples from the residual ore samples.

On completion of the experiments the columns were emptied and the contents dried. From the dry samples, sub-samples were obtained for fire assays and quantitative evaluation of minerals by scanning electron microscopy (QEMSCAN) analysis. The image data from the QEMSCAN was processed and analysed using iDiscover ${ }^{\mathrm{TM}}$ software. The bulk of the samples were used in subsequent cyanide leaching experiments to extract the precious metals.

\subsection{Column cyanide leaching of residue samples from bioleach experiments}

The aim of these experiments was to determine the extent to which precious metals, specifically $\mathrm{Pt}, \mathrm{Pd}$ and $\mathrm{Au}$, could be leached from bioleached residual ore using cyanide solution. The process was operated as a continuous solution fed reactor system as compared to previous work which employed a batch-recycle system, to determine if this would improve the output of Pt specifically.

The bioleach process inevitably produced fines hence the two samples were agglomerated by adding Portland cement ( $5 \mathrm{~g} / \mathrm{kg}$ ore) and water $(8 \mathrm{wt} \%)$ to the samples in buckets, which were tilted and continuously turned for ten minutes. The samples were packed in identical columns to the ones used in the bioleach experiment and were left for 24 hours at a temperature of $50^{\circ} \mathrm{C}$ to cure and form agglomerates. Thereafter a solution of $5 \mathrm{~g} / \mathrm{L}$ sodium cyanide was fed into the columns at a rate of $1 \mathrm{~L} /$ day with no recycle. The solution was buffered using sodium bicarbonate $(1.01 \mathrm{~g} / \mathrm{L})$ and sodium carbonate $(9.32 \mathrm{~g} / \mathrm{L})$ to ensure the $\mathrm{pH}$ remained above 9.6. The columns were operated at a temperature of $50^{\circ} \mathrm{C}$ and aerated at a rate of $130 \mathrm{~mL} / \mathrm{min}$. The effluent solution was sampled every fourth and seventh day for analysis via inductively coupled plasma mass spectrometry (ICP-MS) for precious metals and inductively coupled plasma atomic emission spectroscopy (ICP-AES) for BMs and gangue elements. Additionally, the leachate samples were analysed for thiocyanate via high pressure liquid chromatography (HPLC) and for free cyanide using the Cynoprobe ${ }^{\circledR}$ instrument developed by Mintek. The Cynoprobe ${ }^{\circledR}$ accurately measures free cyanide in solution based on amperometry (Mintek, n.d.). Thus the cyanide consumption calculated from the readings from this instrument is defined as the cyanide used in complexation (all elements), volitalization, conversion to thiocyanate and oxidation either naturally or by reaction with a component of the ore. As before, at the end of all experiments the columns were emptied and the contents dried and sampled, and the sub-samples underwent fire assays and MLA analysis.

\subsection{Results and Discussion}

\subsection{Column bioleaching}

The extractions in Table 4 show that a thermophile bioleach is a promising route for extracting BMs from the Platreef ore especially in comparison to other operations (Saari and RiekkolaVanhanen, 2011) with similar grades of $\mathrm{Cu}$ and $\mathrm{Ni}$, which operate profitably. 
Table 4: Extractions achieved through bioleaching after 304 days

\begin{tabular}{|c|c|c|c|c|c|c|c|c|c|c|c|c|}
\hline & & & $\mathbf{C u}$ & & & $\mathbf{N i}$ & & & Co & & & $\mathrm{Fe}$ \\
\hline & $\begin{array}{c}\text { Solution } \\
\text { Assay }\end{array}$ & $\begin{array}{c}\text { Solid } \\
\text { Residue } \\
\text { Assay }\end{array}$ & Av & $\begin{array}{c}\text { Solution } \\
\text { Assay }\end{array}$ & $\begin{array}{c}\text { Solid } \\
\text { Residue } \\
\text { Assay }\end{array}$ & $\mathbf{A v}$ & $\begin{array}{c}\text { Solution } \\
\text { Assay }\end{array}$ & $\begin{array}{c}\text { Solid } \\
\text { Residue } \\
\text { Assay }\end{array}$ & Av & $\begin{array}{c}\text { Solution } \\
\text { Assay }\end{array}$ & $\begin{array}{c}\text { Solid } \\
\text { Residue } \\
\text { Assay }\end{array}$ & Av \\
\hline & $\%$ & $\%$ & $\%$ & $\%$ & $\%$ & $\%$ & $\%$ & $\%$ & $\%$ & $\%$ & $\%$ & $\%$ \\
\hline $\begin{array}{c}\text { Column } \\
1 \\
\text { Column }\end{array}$ & 96.5 & 66.9 & 81.7 & 56.6 & 77.4 & 67.0 & 35.8 & 45.7 & 40.8 & 30.6 & 13.5 & 22.0 \\
\hline 2 & 101.9 & 84.2 & 93.0 & 66.3 & 83.4 & 74.9 & 45.3 & 61.2 & 53.3 & 47.9 & 18.1 & 33.0 \\
\hline
\end{tabular}

The leach curves in Figure 1 show that the column run with the smaller size fraction $(-6 \mathrm{~mm}$ $+1 \mathrm{~mm}$ ) performed better than that with the larger size range $(-25 \mathrm{~mm}+1 \mathrm{~mm})$ in all cases. There is quite a large discrepancy between the results for $\mathrm{Cu}$ and $\mathrm{Ni}$, obtained by solution assay of leach samples and those obtained by solid residue assay of ore samples. In each case the difference between the two is greater than the normally accepted level of $10 \%$, and whereas solution assay shows that extraction of $\mathrm{Cu}$ was higher than $\mathrm{Ni}$, the solid residue assay indicates otherwise. It can be speculated that the source of this discrepancy may lie with the sub-sampling of the residual ore. The sub-samples may have been too small and unrepresentative in an effort to conserve a sufficient size sample for the next experiment. Therefore, although the solid assay analyses may have been accurate, they were performed on what may have been unrepresentative samples. Considering that coarse ore was used, it is easy to understand the difficulty in obtaining small representative samples. In addition, a small set of samples, representing less than $10 \%$ of the total solution samples were duplicated and analysed by an independent laboratory to verify the accuracy of the ICP analysis used for all the samples. The results tallied within $2 \%$ of both sets of results. However, because only a small sample was used, overall the actual source of the discrepancy between solid and solution assay could not be determined conclusively. However the values for both assays are an indication of the leachability of the ore and its suitability for further consideration for heap leaching.

It is quite noticeable from Table 4 and Figure 1 that the extraction of $\mathrm{Ni}$ was not as high as $\mathrm{Cu}$. This is opposite to what was observed in earlier test work on concentrate (Mwase et al., 2012a; Mwase et al., 2012b) in which the extent and rate of extraction $\mathrm{Ni}$ was higher than $\mathrm{Cu}$. It is suggested that in the concentrate leaching galvanic leaching facilitated almost complete extraction of $\mathrm{Ni}$ and faster leaching than $\mathrm{Cu}$. This was partially due to the intergrowth of pentlandite, and chalcopyrite mineral grains, but for the most part due to physical contact between these mineral grains due to the physical nature of the sample; it had been finely milled and mixed into a slurry. However QEMSCAN analysis of selected ore particles from the whole ore bioleach experiment shows little or no contact between pentlandite and chalcopyrite mineral grains, and hence galvanic leaching of $\mathrm{Ni}$ in preference to $\mathrm{Cu}$ could not take place. It is also suggested that, unlike the flotation concentrate used in earlier studies, the $\mathrm{Ni}$ in the ore was not largely pentlandite but that some of it deported to other non-sulphide minerals such as the silicates. Hence it is not leachable via bioleaching. This is in line with flotation test work on identical ore samples which showed only up to $75 \%$ of Ni was recoverable by flotation (Schay, 2009; Mogoseti, 2006). However, QEMSCAN analysis of both samples showed that the remaining $\mathrm{Ni}$ was almost entirely in the form of pentlandite and copper was entirely in the form of chalcopyrite. But there may have been a limitation with the QEMSCAN and a failure to recognize the Ni associated with silicates. Additionally, a number of particles had cracks between chalcopyrite and pentlandite mineral grains, and the bulk silicate mineral grains. It is postulated that these cracks are a result of the HPGR processing and not solution erosion, otherwise the minerals would have leached out. This would suggest that the solution flow 
pattern, or hydrodynamics play a critical role in the leaching of the minerals; the minerals may be liberated through the cracks, but they will not leach if no solution is in contact with the mineral grains.

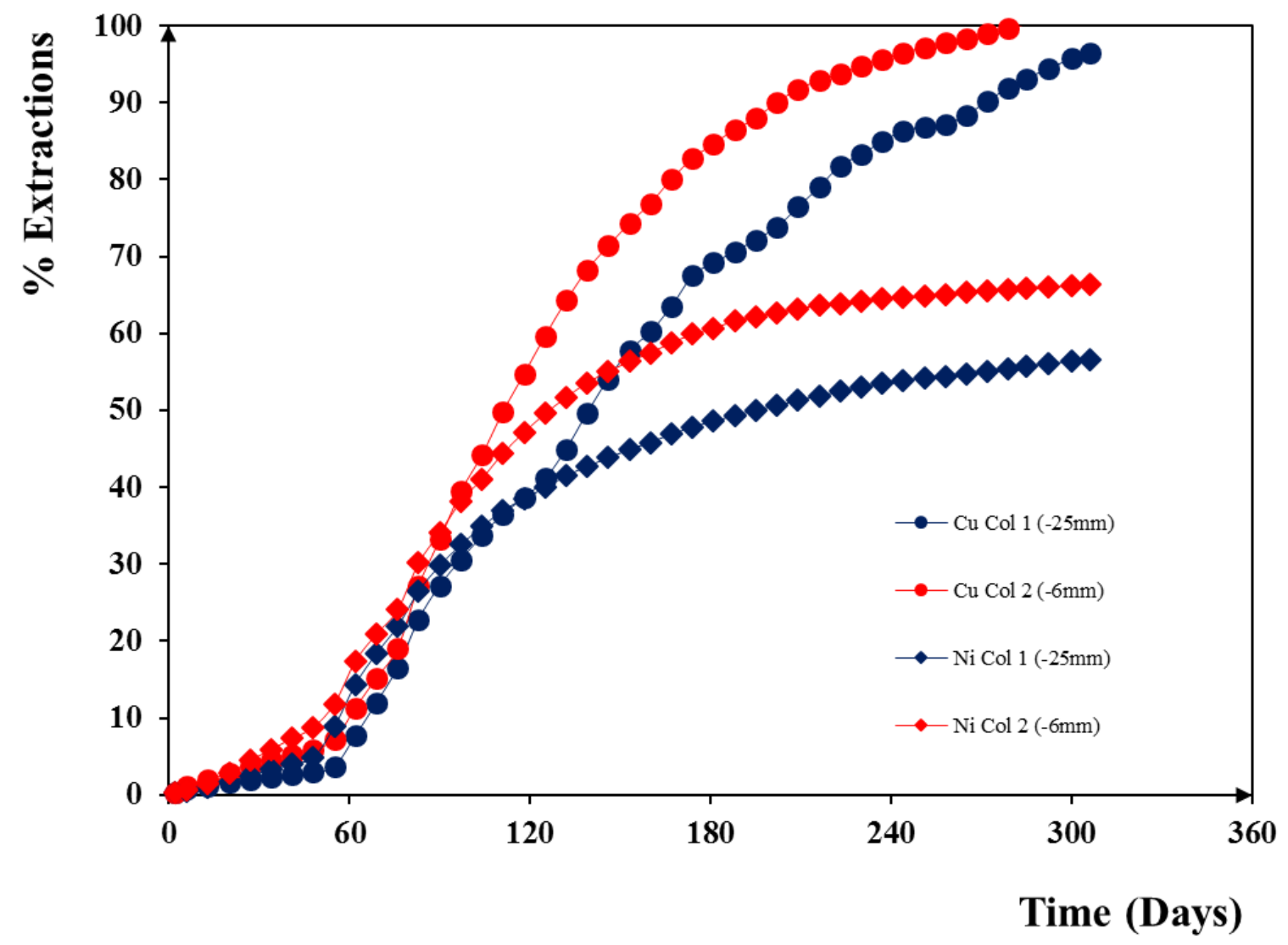

Figure 1: $\mathrm{Cu}$ and Ni leach curves.

The dissolution of gangue minerals was quite high initially and reduced almost mid-way through the leaching period. This corresponded with the patterns of $\mathrm{pH}$ and redox potential in Figures 2 and 3 . The columns were rinsed abiotically with $30 \mathrm{~g} / \mathrm{L}$ sulphuric acid for the first 44 days and $\mathrm{pH}$ and ORP values were consequently low. After day 44, when the columns were inoculated and the bioleach process was initiated, the $\mathrm{pH}$ of the feed solution was 1.3 before it was fed into the columns, but up until day 180 it increases to higher values. This is an indication of acid consumption by the gangue minerals which are largely silicates or by consumption by the bio-oxidation process. After day 180, the $\mathrm{pH}$ starts to drop showing that the acid consuming portion of the gangue is mostly leached and the acid fed into the columns and that which is produced from oxidation of sulphur is no longer consumed by the acid-consuming gangue minerals. A full scale operation will have to carefully consider the influence of gangue elements on acid consumption, possible inhibition of microbial activity, on the viscosity and other properties of recycled leachate solution and the environmental impact of having large quantities of sulphates in the effluent for disposal. Although the lime/limestone requirements may be high, the sulphates may be mitigated by neutralization and gypsum precipitation. 


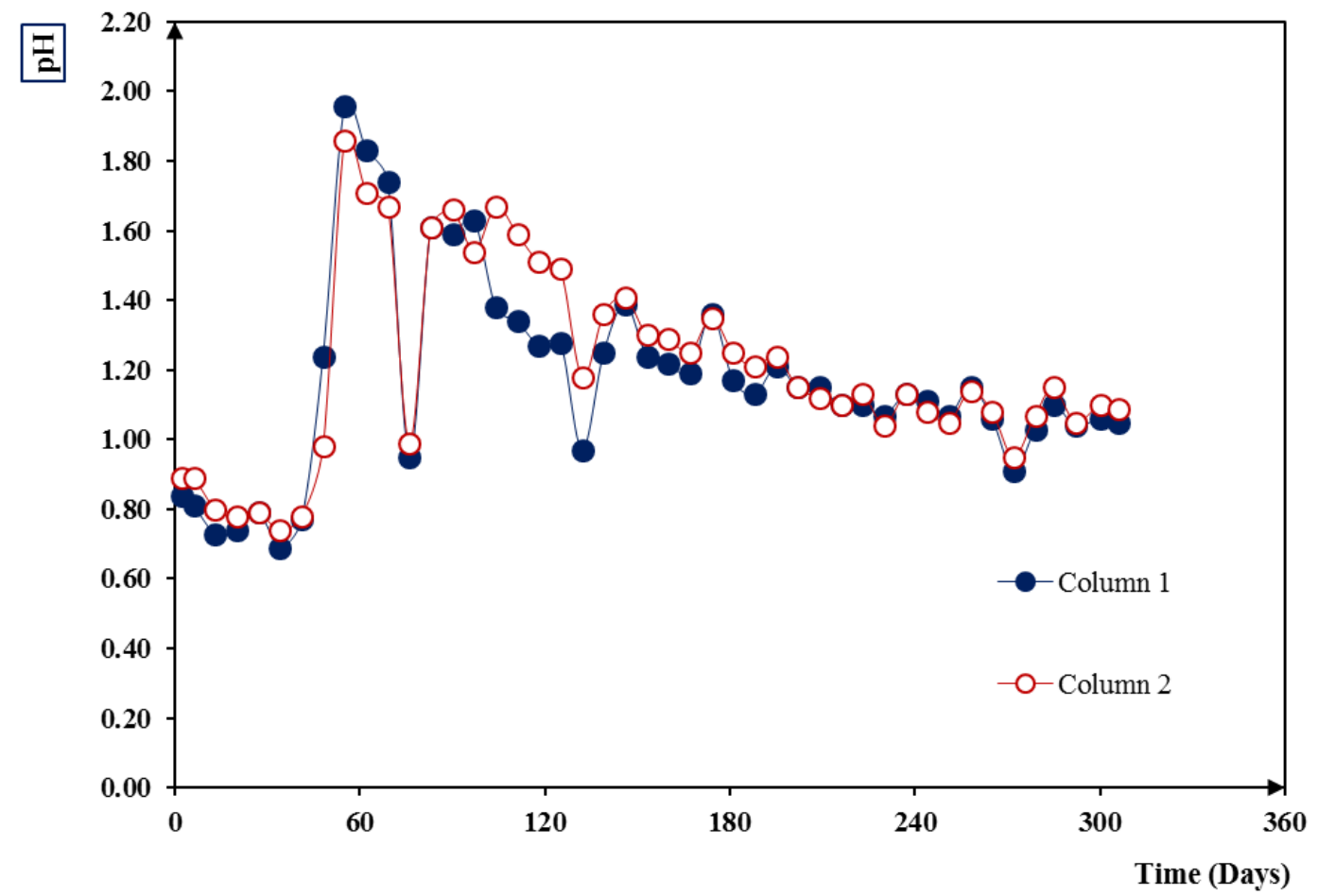

Figure 2: pH profiles from bioleach experiments.

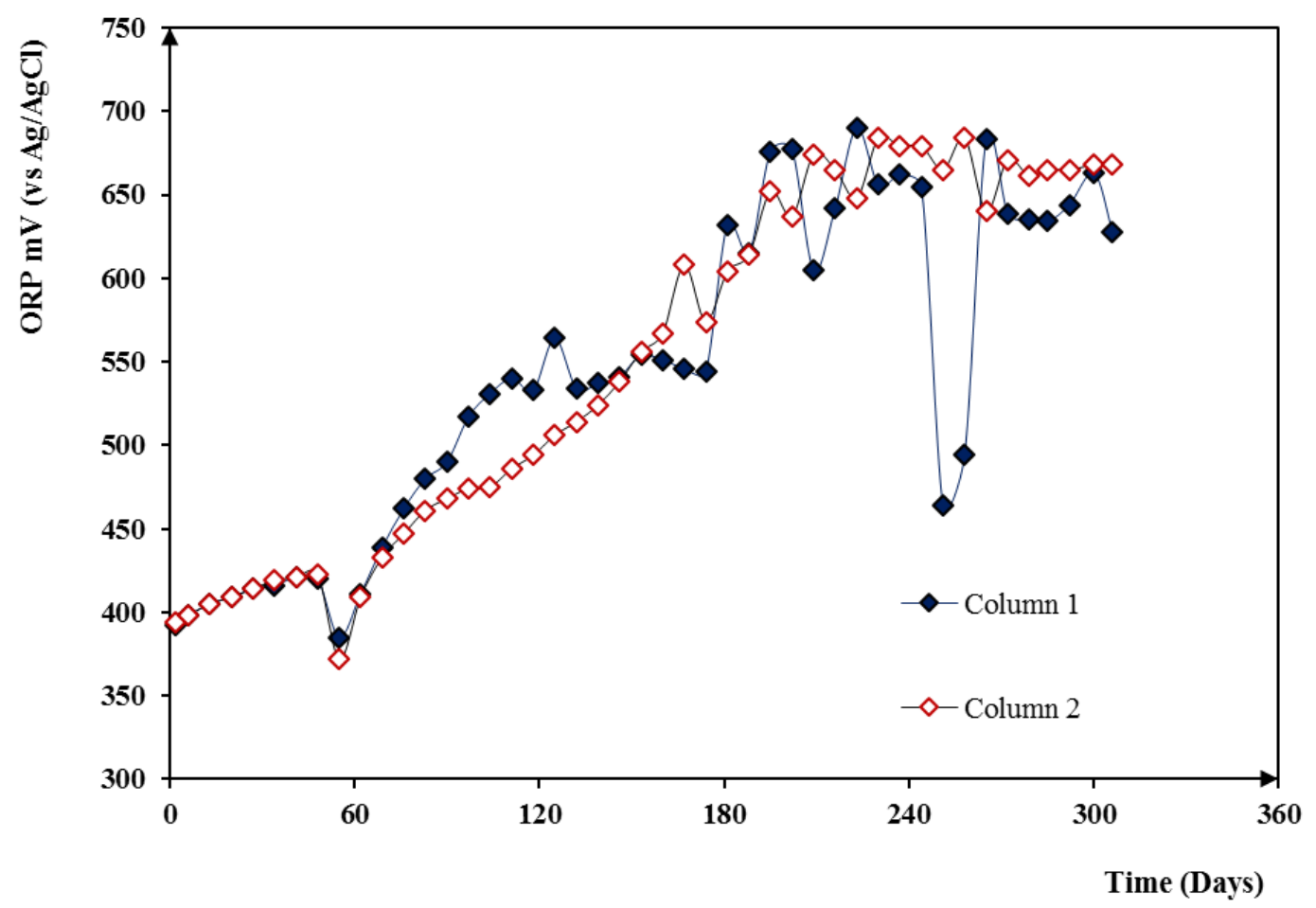

Figure 3: ORP profiles during the bioleach experiments. 
Table 5: Grade of ore going into cyanide leach

\begin{tabular}{llllllll}
\hline & $\mathbf{P t}$ & $\mathbf{P d}$ & $\mathbf{A u}$ & $\mathbf{C u}$ & $\mathbf{N i}$ & $\mathbf{F e}$ & $\mathbf{S}$ \\
& $\mathbf{g / t}$ & $\mathbf{g} / \mathbf{t}$ & $\mathbf{g} / \mathbf{t}$ & $\mathbf{\%}$ & $\mathbf{\%}$ & $\mathbf{\%}$ & $\mathbf{\%}$ \\
\hline Column 1 $(-25 \mathrm{~mm})$ & 2.3 & 2.3 & 0.3 & 0.04 & 0.08 & 7.5 & 0.3 \\
Column 2 $(-6 \mathrm{~mm})$ & 2.3 & 2.5 & 0.4 & 0.02 & 0.06 & 7.1 & 0.2 \\
\hline
\end{tabular}

The grade of the ore with regards to the precious and base metals and total sulphur, going into the cyanide column leach is detailed in Table 5. The bulk of the ore (50-60\%) was mainly silicate minerals with silicon as an element accounting for $27 \%$ of both ore samples by mass.

Table 6: Extractions achieved through cyanide leaching after 60 days

\begin{tabular}{|c|c|c|c|c|c|c|c|c|c|}
\hline & & & $\mathbf{P t}$ & & & Pd & & & $\mathbf{A u}$ \\
\hline & $\begin{array}{l}\text { Solution } \\
\text { Assay } \\
\%\end{array}$ & $\begin{array}{l}\text { Solid } \\
\text { Residue } \\
\text { Assay } \\
\%\end{array}$ & $\begin{array}{l}\text { Av } \\
\%\end{array}$ & $\begin{array}{l}\text { Solution } \\
\text { Assay } \\
\%\end{array}$ & $\begin{array}{l}\text { Solid } \\
\text { Residue } \\
\text { Assay } \\
\%\end{array}$ & $\begin{array}{l}\text { Av } \\
\%\end{array}$ & $\begin{array}{l}\text { Solution } \\
\text { Assay } \\
\%\end{array}$ & $\begin{array}{l}\text { Solid } \\
\text { Residue } \\
\text { Assay } \\
\%\end{array}$ & $\begin{array}{l}\text { Av } \\
\%\end{array}$ \\
\hline Column 1 & 41.0 & 58.3 & 49.7 & 79.3 & 81.4 & 80.4 & 80.6 & 85.5 & $\overline{83.1}$ \\
\hline Column 2 & 55.9 & 59.8 & 57.8 & 105.3 & 94.3 & 99.7 & 88.4 & 92.3 & 90.3 \\
\hline
\end{tabular}

Table 7: Concentration of Pt in solution from Figure

\begin{tabular}{llll}
\hline & $\begin{array}{l}\text { 4 days } \\
\boldsymbol{\mu g} / \mathrm{L}\end{array}$ & $\begin{array}{l}\text { Next 28 days } \\
\boldsymbol{\mu g} / \mathrm{L}\end{array}$ & $\begin{array}{l}\text { Last 28 days } \\
\boldsymbol{\mu g} / \mathrm{L}\end{array}$ \\
\hline Column 1 $(-25 \mathrm{~mm})$ & 340 & 60 & $5-10$ \\
Column 2 $(-6 \mathrm{~mm})$ & 490 & 60 & $5-10$ \\
\hline
\end{tabular}

Table 6 shows the extractions of precious metals achieved based on data from solution assays and from fire-assays of ore samples before and after the leaching experiment. With the exception of Pd for column 1 these results, between solution and solid assay, tally much better than those in Table 4 for the bioleach experiment. This may be due to the fact that the solid assays were conducted on much larger and thus more representative sub-samples than the bioleach experiment. The results show that the use of a continuous system has improved the rate and extent of precious metals extraction considerably from the results achieved on concentrate material, given the similar mineralogy of the ore. Of particular note is the $53 \% \mathrm{Pt}$ extraction achieved with the $-6 \mathrm{~mm}+1 \mathrm{~mm}$ size fraction in 32 days, as compared to the $35 \%$ achieved on concentrate in 45 days (Mwase et al., 2012a). In both columns the Pd and $\mathrm{Au}$ leached out rapidly (Figures 5 and 6), whereas Pt leaches out at a much slower rate and via a distinct pattern (Figure 4). A certain portion (about 30\%) is rapidly leached in 4 days, followed by another $23 \%$ over the next 28 days, which is slower to leach out, while the remaining $47 \%$ leaches at a significantly slower rate than the first $53 \%$. This can been further seen in Table 7 , which shows the actual concentrations of Pt in solution over the three sections of the leach curves in Figure 4.

The lack of scatter in Figures 5 and 6 is due to the unexpected rapid leaching of Pd and Au. As stated already, this test work is a follow-up from test work conducted on concentrate, where such rapid leaching of precious metals did not occur. Furthermore, the sampling programme 
took into account that the test work was on coarse ore and thus was expected to proceed at slow leaching rates.

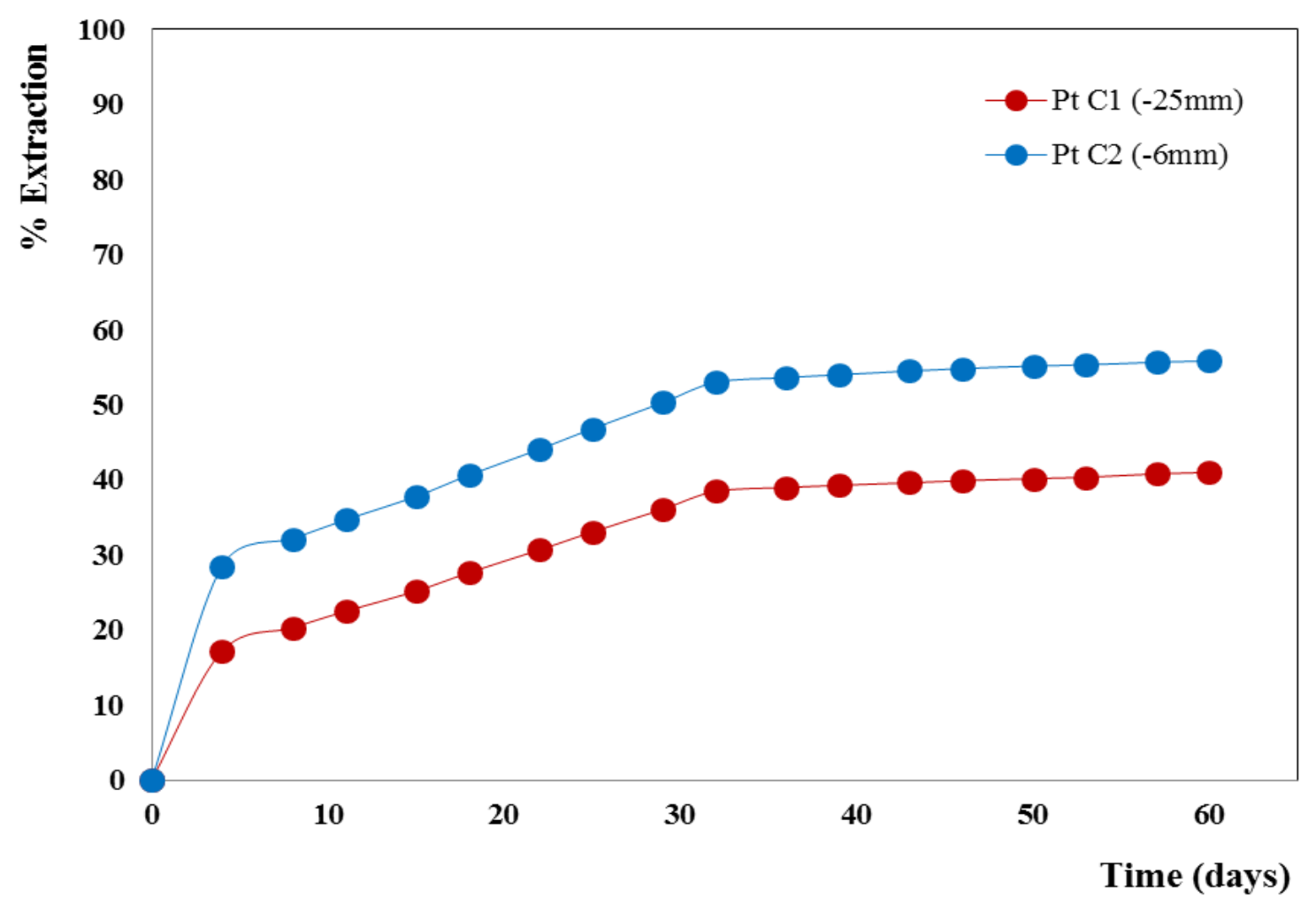

Figure 4: Pt leach curves from cyanide experiments.

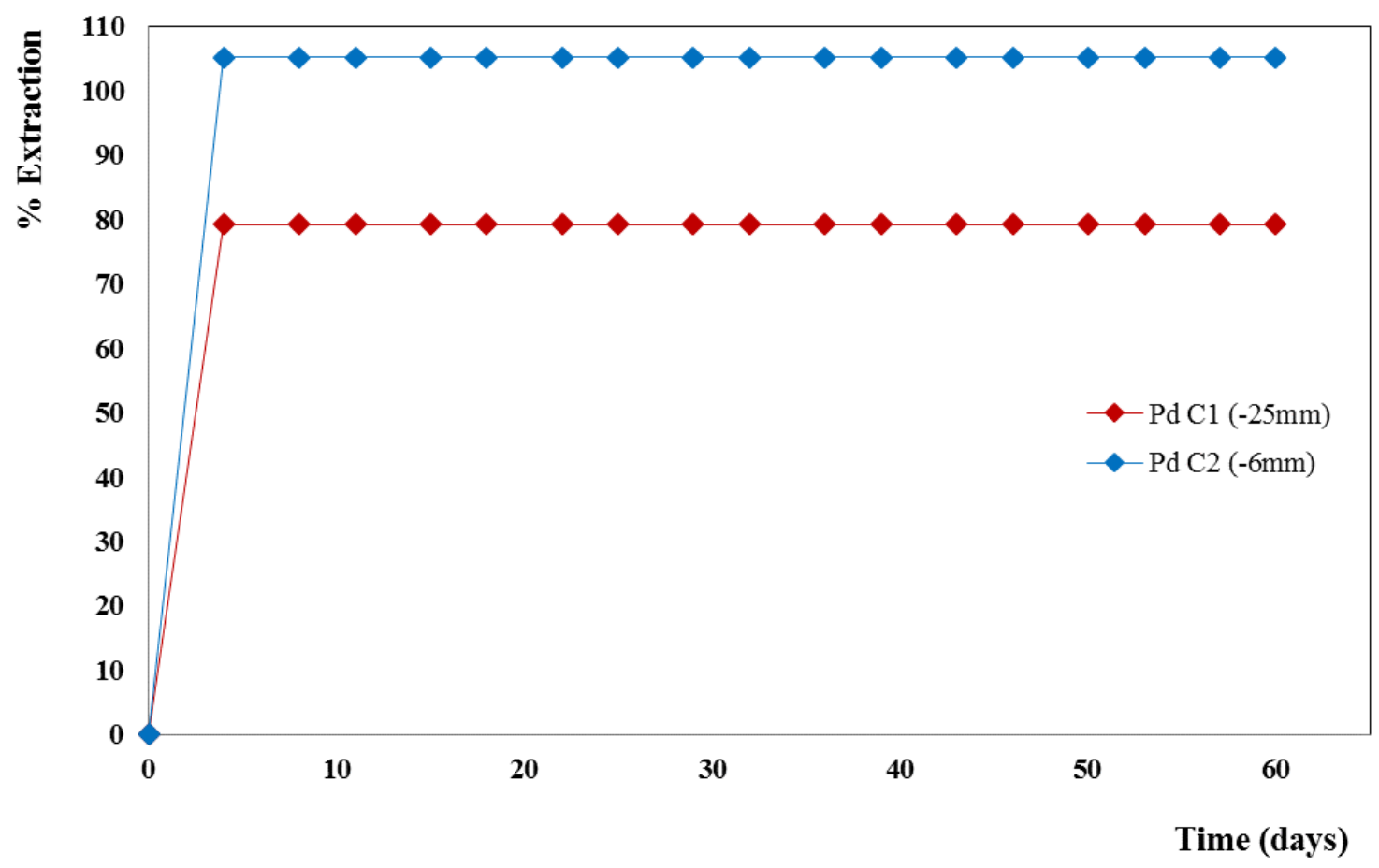

Figure 5: Pd leach curves from cyanide experiments. 


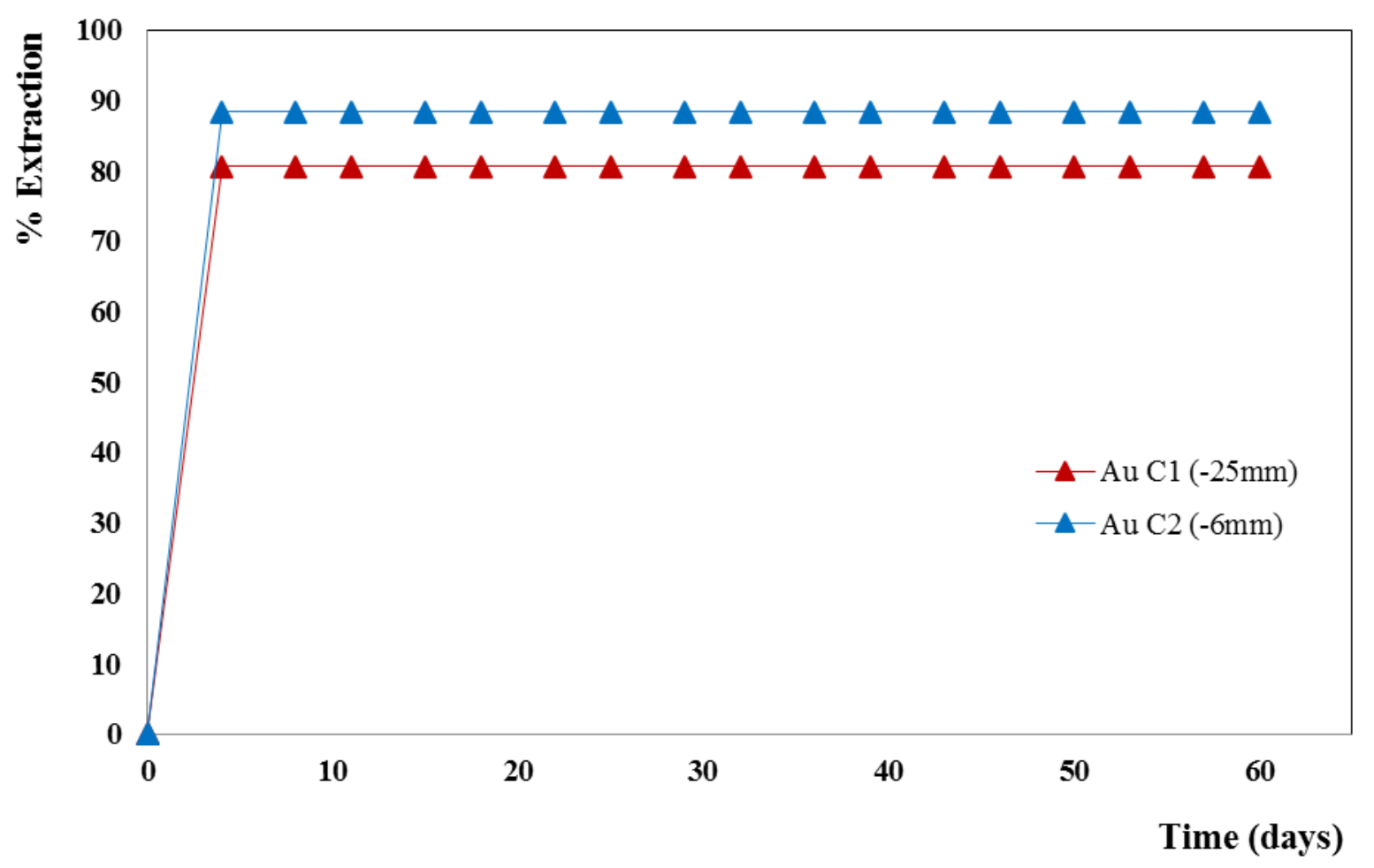

Figure 6: Au leach curves from cyanide experiments.

Table 8 shows the results from the MLA analysis on an ore residue sub-sample from column 2. Of the remaining $\mathrm{Pt}$ and $\mathrm{Pd}$ minerals, $80 \%$ were arsenides, with sperrylite $\left(\mathrm{PtAs}_{2}\right)$ accounting for $76 \%$ of the total PGM content and palarstanide $\left(\mathrm{Pd}_{8} \mathrm{Sn}_{1.5} \mathrm{As}_{1.5}\right)$ accounting for $3 \%$. Tellurides (8\%), sulpharsenides (6\%), alloys (4\%) and sulphides $(2 \%)$ made up the remaining $\mathrm{Pt}$ and $\mathrm{Pd}$ minerals, with trace amounts of gold and silver entirely from electrum. The other $\mathrm{Pt}$ and $\mathrm{Pd}$ minerals of note are maslovite (PtBiTe) and platarsite [( $\mathrm{Pt}, \mathrm{Rh}, \mathrm{Ru}) \mathrm{AsS}]$ both accounting for $6 \%$ each. All the remaining precious metals minerals were generally not well liberated. The sulpharsenides had the highest liberation with an exposed surface area of $26 \%$, followed by the sulphides, tellurides and arsenides with an exposure range of $2-7 \%$. The remaining electrum and alloys were $100 \%$ locked and this would explain their inability to be leached. However, for the other mineral groups it is most likely a mineralogical characteristic that prevented their leaching, as leaching, unlikely flotation, requires only partial exposure. The exposure of the Pt sulpharsenides, tellurides and arsenides suggests that they are resistant to cyanide leaching under the prevailing conditions. In the case of sperrylite it confirms what was established during the first phase of tests on the concentrate material (Mwase et al., 2012a) as the present results are almost identical to those obtained for concentrate. From this work it becomes clear that the key to making the PGM heap leach process viable rests with understanding why sperrylite leaches slowly in cyanide and finding a method to leach the sperrylite at a faster rate in a heap under the prevailing conditions. Additionally, the lower extraction of $\mathrm{Pt}$, relative to $\mathrm{Pd}$ and $\mathrm{Au}$, can be explained by the high deportment of $\mathrm{Pt}$ to sperrylite and to a lesser extent maslovite and platarsite. The lower extraction of $\mathrm{Pt}$ as compared to Pd can also be attributed to the high deportment of Pd to the tellurides which appear to be cyanide soluble, in contrast to the arsenides and sulpharsenides which are resistant to cyanide leaching. Comparing the above data to the pre-bioleach MLA analysis, it is suggested that fractions of Pt and Pd leached were mostly from the minerals moncheite and merenskyite. Although MLA anaylsis was not conducted on the whole ore samples post-bioleach, the 
analysis of indicates that the process conditions of the bioleach have no influence on the PGM mineralogy of the Platreef ore concentrate (Mwase et al., 2012a). The major mineral groups, tellurides, aresenides, sulphides and sulpharsenides, remain unaltered after the bioleach process, and given the otherwise strong similarity between MLA analysis of whole ore and concentrate, it is reasonable to assume this holds true for the bioleach whole ore residues.

Table 8: MLA analysis-PGM minerals in residue from column 2

\begin{tabular}{llll}
\hline Groups & Mineral & Formula & \% Area \\
\hline Electrum & Electrum & $\mathrm{AuAg}$ & $<0.1$ \\
& PtElectrum_HiAg & $\mathrm{PtAgAu}$ & 0.1 \\
\hline Alloys & Ferroplatinum & $\mathrm{PtFe}$ & 2.6 \\
& Atokite & $(\mathrm{Pd}, \mathrm{Pt})_{3} \mathrm{Sn}$ & 0.2 \\
& Sudburyite & $\mathrm{PdSb}$ & 0.6 \\
& Stumpflite & $\mathrm{Pt}(\mathrm{Sb}, \mathrm{Bi})$ & $<0.1$ \\
& Sobolevskite & $\mathrm{PdBi}$ & $<0.1$ \\
& PtPdRhSe & $\mathrm{PtPdRhSe}$ & 0.2 \\
\hline Sulphides & Cooperite & $\mathrm{PtS}$ & 1.6 \\
& Braggite & $\mathrm{PtPdS}$ & 0.1 \\
\hline Arsenides & Sperrylite & $\mathrm{PtAs} 2$ & 76.0 \\
& Arsenopalladinite & $\mathrm{Pd}(\mathrm{As}, \mathrm{Sb})_{3}$ & 0.7 \\
& PtPdAs & $(\mathrm{Pt}, \mathrm{Pd}) \mathrm{As}$ & 0.1 \\
& Palarstanide & $\mathrm{Pd} \mathrm{Sn}_{1.5} \mathrm{As} \mathrm{s}_{1.5}$ & 3.4 \\
\hline Sulpharsenides & Platarsite & $(\mathrm{Pt}, \mathrm{Rh}, \mathrm{Ru}) \mathrm{AsS}$ & 6.4 \\
& PtPdSulpharsenide & $(\mathrm{Pt}, \mathrm{Pd}) \mathrm{AsS}$ & 0.1 \\
\hline Tellurides & Maslovite & $\mathrm{PtBiTe}$ & 6.0 \\
& Moncheite & $(\mathrm{Pt}, \mathrm{Pd})(\mathrm{Te}, \mathrm{Bi})_{2}$ & $<0.1$ \\
& Kotulskite & $\mathrm{Pd}(\mathrm{Te}, \mathrm{Bi})$ & 2.1 \\
\hline
\end{tabular}

\subsubsection{Dissolution of major base and gangue elements in cyanide leach}

The leaching of other elements was also evaluated to determine the impact it would have on the process. Table 9 shows the concentrations of the elements that were present in solution over various sampling periods. This data is more useful than percentage extractions, as these would not accurately reflect the prevailing situation. In the case of the BMs, the extraction figures seemed high only because they were calculated against residual amounts that remained after the bioleach. Similarly for the gangue elements, they seemed low only because the bulk of the ore was composed of gangue elements. Table 9 takes into account the first 32 days, as this seems to be the period when the process is most feasible in terms of precious metals extraction. The levels of dissolution were high relative to the precious metals concentrations (which were in the ppb levels), but this did not appear to interfere with the extraction of the precious metals. Although $\mathrm{Si}$ was the highest, there is no literature indicating the existence of $\mathrm{Si}-\mathrm{CN}$ complexes, and therefore it is postulated that it is most likely colloidal or sodium silicates that have been detected. Of higher concern is the influence of $\mathrm{Cu}, \mathrm{Ni}$ and $\mathrm{Fe}$ in the downstream processing of pregnant liquor solution to recover the precious metals. Test work has shown that the presence of these elements at concentrations of around $50 \mathrm{ppm}$ increases the amount of carbon and resins required in recovery of precious metals (Schoeman et al., 2012; Synders et al., 2012). However no literature has been found on the influence of the observed levels of $\mathrm{Si}$ on the adsorption process. In an industrial scale operation, where a solution recycle system is used, these levels of $\mathrm{Cu}$, $\mathrm{Ni}$ and $\mathrm{Fe}$ could build up to the $200-300 \mathrm{mg} / \mathrm{L}$ range, at which point they become problematic to the recovery of precious metals. At these levels there are various methods that can be considered to pre-treat the solution before precious metals recovery. These methods involve separating the metal cyanide complexes from the pregnant solution selectively and 
without interfering with the precious metals, and recovering $\mathrm{Cu}$ and $\mathrm{Ni}$ as saleable sulphide products or a higher purity product such as cathode. Stewart and Kappes (2011) report that the more established or piloted methods include the Acidification-Volatilization-Recovery (AVR) method, electrowinning, ion exchange processes (AuGMENT and Vitrokele) and sulphide precipitation (Sulfidation, Acidification, Recycling, Thickening-SART and Metallgesellschaft Natural Resources process-MNR), while Lien (2008) suggests the use of the EMS® (Engineered Membrane Separation) system. The resulting solution containing HCN can then be processed to obtain $\mathrm{Ca}$ or $\mathrm{Na}$ cyanide salts that can be returned to the heap.

Table 9: $\mathrm{Cu}, \mathrm{Ni}, \mathrm{Fe}$ and $\mathrm{Si}$ concentration over a 32 day leaching period

\begin{tabular}{llcc}
\hline & & $\begin{array}{c}\text { First 4 days } \\
\text { mg/L }\end{array}$ & $\begin{array}{c}\text { Next 28 days } \\
\text { mg/L }\end{array}$ \\
\hline $\mathrm{Cu}$ & Column 1 & 40 & $6-20$ \\
& Column 2 & 30 & $3-8$ \\
$\mathrm{Ni}$ & Column 1 & 22 & $4-10$ \\
& Column 2 & 36 & $1-5$ \\
$\mathrm{Fe}$ & Column 1 & 33 & $16-28$ \\
& Column 2 & 28 & $10-20$ \\
$\mathrm{Si}$ & Column 1 & 200 & $500-700$ \\
& Column 2 & 180 & $500-700$ \\
\hline
\end{tabular}

\subsubsection{Sodium cyanide consumption}

The amount of sodium cyanide used was calculated by determining the amount fed to the columns up to a particular sampling point and then calculating the amount that was left afterwards by determining the concentration of the effluent solution using the Cynoprobe ${ }^{\circledR}$ instrument. This amount was expressed as a percentage of the original amount fed into the column at that particular sampling point. Figure 8 shows that on average only half the cyanide in solution was consumed suggesting that the process could still occur using a solution concentration of $2.5 \mathrm{~g} / \mathrm{L}$. Gold heap leach operations typically use 0.1-0.5 g/L (Kappes, 2002) or 0.15-2.5 g/L (Chamberlain and Pojar, 1984), depending on the literature source. The discrepancy in solution concentration ranges is likely due to varying grades of ores and other factors such as the presence of copper, iron, organic materials and silver which can make the ore refractory to cyanide leaching. As it stands, the cyanide consumptions in columns 1 and 2 after 32 days have been determined as 16.5 and $27.5 \mathrm{~kg} / \mathrm{t}$ respectively, whereas typical gold heap leaching operations for run-of-mine and crushed ore (excluding refractory ores) are reported to consume 0.1-2.5 kg/t (Roxburgh, 2011; Marsden and House, 2006; Kappes, 2002). On the other hand, cyanide tank leaching operations on concentrate residues of bacterial oxidation are reported to experience cyanide consumptions of $15-28 \mathrm{~kg} / \mathrm{t}$ in actual operations (Aswegen et al., 2007; Miller and Brown, 2005) and in the range of 2-122 kg/t in various test work projects (Miller and Brown, 2005). However Roxburgh (2011) reports that for gold heap leaching an actual heap operation uses only 40-65\% of the cyanide used in column test work. In addition, Stewart and Kappes (2011) report that certain gold minerals have exhibited a higher affinity for cyanide in environments with high $\mathrm{Cu}$ and sulphur content, resulting in preferential leaching of the gold. Thus much lower concentrations of cyanide solution and no treatment prior to recovery were required. Furthermore, $\mathrm{Pt}, \mathrm{Pd}$ and $\mathrm{Au}$ from stronger complexes with cyanide than elements like $\mathrm{Cu}, \mathrm{Ni}, \mathrm{Fe}$ and $\mathrm{Co}$ (van Rensburg and Lotz, 2010; Marsden and House, 2006); hence with lower cyanide concentrations there may be preferential leaching of precious metals. The bioleached residues of Platreef ore are yet to be tested with lower sodium cyanide concentrations to determine if the minerals in Platreef also exhibit a similar 
characteristic. The only foreseen trade-off is that leaching may not occur as rapidly as it has presently occurred, if lower solution concentrations are used.

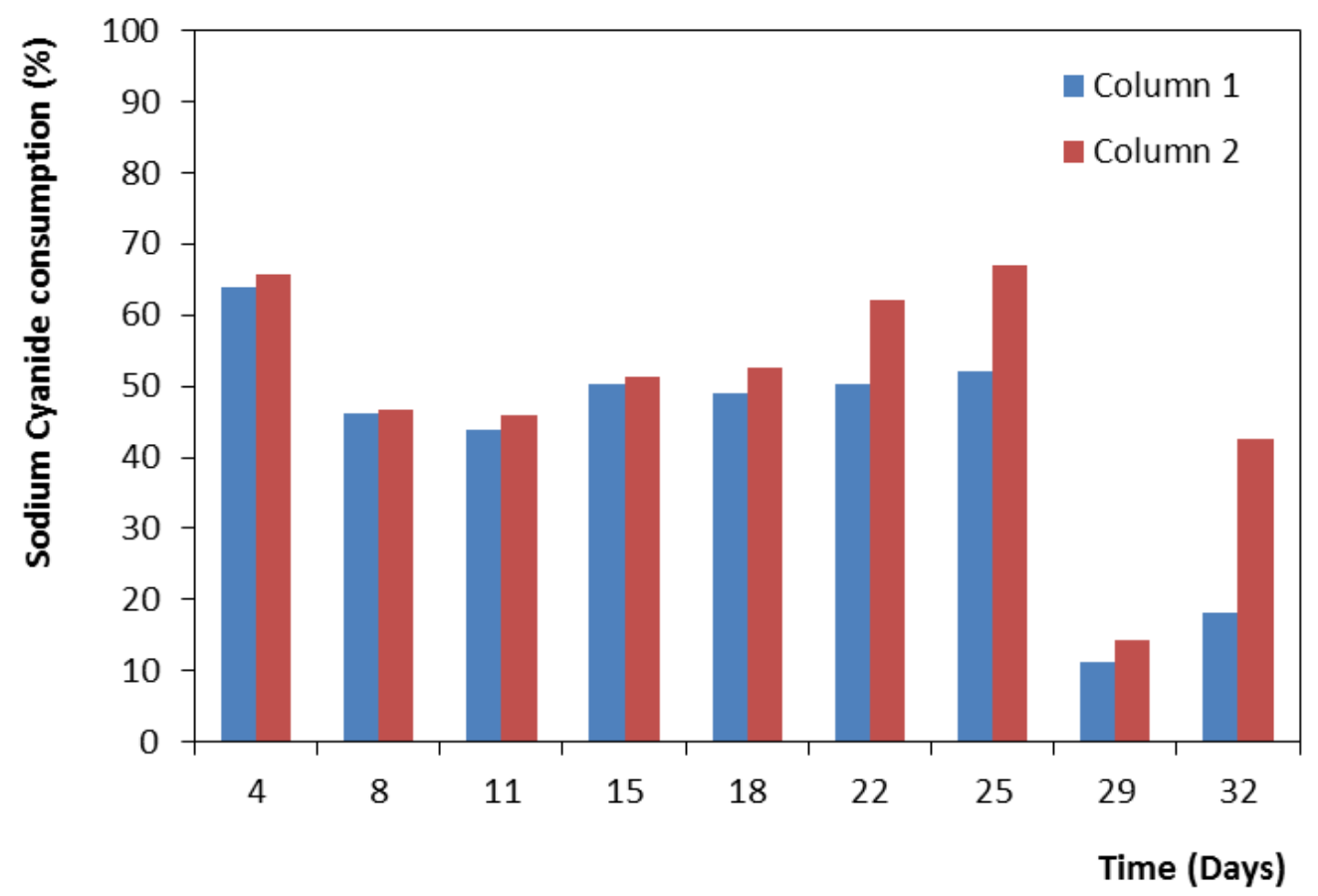

Figure 7: Cyanide consumed as a percentage of cyanide put in at that point.

In order to further compare with gold heap leach operations, the amount of sodium cyanide consumed was analysed as sodium cyanide consumed per ounce of precious metals leached (kg/oz.). This was considered a useful basis of analysis, taking into account that this process leaches multiple precious metals at the same time. Literature (Roxburgh, 2011; Kappes, 2002; van Zyl et al., 1990; Chamberlain and Pojar, 1984) indicates that the grades of gold ores heap leached range from $<0.1-1.8 \mathrm{~g} / \mathrm{t}$ and consume in the range of $0.1-2.5 \mathrm{~kg} / \mathrm{t}$ of sodium cyanide in both column and actual heap operations. The same literature associates the lower cyanide consumptions with lower grade ores and high consumptions with higher grade ores. Thus, in making this comparison it is assumed that a $<0.1 \mathrm{~g} / \mathrm{t}$ ore uses $0.1 \mathrm{~kg} / \mathrm{t}$, and a $1.8 \mathrm{~g} / \mathrm{t}$ ore uses 2.5 $\mathrm{kg} / \mathrm{t}$ for $80 \%$ recovery of $\mathrm{Au}$; the calculated consumption range for gold operations is hence $39-54 \mathrm{~kg} / \mathrm{oz}$. Similar calculations were conducted for the cyanide column test on Platreef ore using the actual amount of cyanide consumed from Figure 7 and the recoveries of $\mathrm{Pt}, \mathrm{Pd}$ and $\mathrm{Au}$ up to the 32nd day. If only column 2 is considered, Table 10 shows that in the first 4 days the consumption is comparable to the operating parameters of typical gold heap leaches. The major contributing factors to this are the elevated operating temperature, which has increased the rate of extraction and most likely reduced the consumption of cyanide to a lower amount than would have been required at ambient temperature, and the higher than usual concentration of cyanide reagent used for leaching. However, after 4 days the consumption increases sharply, as Pt is the only metal being extracted, and it is leaching out at a much slower rate. For this period the process becomes uneconomical, as the Pt extracted barely covers the cost of cyanide alone without considering other operational costs. However, as stated earlier, there is still precedence to evaluate the use of lower sodium cyanide concentrations for this part of the leach and in fact throughout the whole operation. 
Table 10: Sodium cyanide consumed per oz. of precious metals leached

\begin{tabular}{lccccc}
\hline & $\begin{array}{c}\text { NaCN } \\
\text { used in kg } \\
\times \mathbf{1 0}^{-3}\end{array}$ & $\begin{array}{c}\text { Pt leached } \\
\text { in oz. } \\
\times \mathbf{1 0}^{-5}\end{array}$ & $\begin{array}{c}\text { Pd leached } \\
\text { in oz. } \\
\times \mathbf{1 0}^{-4}\end{array}$ & $\begin{array}{c}\text { Au leached } \\
\text { in oz. } \\
\times \mathbf{1 0}^{-5}\end{array}$ & $\begin{array}{c}\text { First 4 } \\
\text { days } \\
(\mathbf{k g} / \mathbf{o z} .)\end{array}$ \\
\hline Column1 $(-25 \mathrm{~mm})$ & 9.5 & 3.5 & 1.6 & 2.4 & $\mathbf{4 4 . 5}$ \\
Column 2 $(-6 \mathrm{~mm})$ & 9.7 & 5.0 & 1.9 & 2.5 & $\mathbf{3 6 . 0}$ \\
\hline & $\begin{array}{c}\text { NaCN } \\
\text { used in kg } \\
\times \mathbf{1 0}^{-3}\end{array}$ & $\begin{array}{c}\text { Pt leached } \\
\text { in oz. } \\
\times \mathbf{1 0}^{-5}\end{array}$ & $\begin{array}{c}\text { Pd leached } \\
\text { in oz. } \\
\times \mathbf{1 0}^{-4}\end{array}$ & $\begin{array}{c}\text { Au leached } \\
\text { in oz. } \\
\times \mathbf{1 0}^{-5}\end{array}$ & $\begin{array}{c}\text { Next 28 } \\
\text { days } \\
\text { (kg/oz.) }\end{array}$ \\
\hline Column1 $(-25 \mathrm{~mm})$ & 41.7 & 4.3 & - & - & $\mathbf{9 5 9 . 3}$ \\
Column 2 $(-6 \mathrm{~mm})$ & 58.5 & 4.3 & - & - & $\mathbf{1 3 6 0 . 5}$ \\
\hline
\end{tabular}

\subsubsection{Thiocyanate conversion}

The formation of thiocyanate is of concern in this process as high levels of this compound in the effluent solution would suggest a high amount of sodium cyanide being consumed for nonvalue purpose and an environmental risk. Unlike $\mathrm{Cu}$ and $\mathrm{Ni}$ cyanide complexes which can be processed to obtain saleable products, and the process effluent which can be treated to regenerate cyanide, the cyanide converted to thiocyanate is completely lost. Additionally, levels of thiocyanate salts higher than $100 \mathrm{ppm}$, adsorbed to either the resins or carbon used for precious metals recovery, have shown to reduce elution of $\mathrm{Pt}, \mathrm{Pd}$ and $\mathrm{Au}$ from the resins and carbon (Snyders et al., 2012). Figure 8 indicates that the presence of thiocyanate is likely to have a more negative effect on the recovery of the precious metals. Although initial conversion to thiocyanate is high, it gradually decreases over the 32 day period and the final total conversions for columns 1 and 2 are 12.7 and 6.5\% respectively (Figure 9). These percentages are not excessive and not necessarily a hindrance to commercial operation, but this may be a different case when more diluted solutions of cyanide are used. The pattern in Figures 8 and 9 suggests the presence of reduced sulphur compounds which readily react with cyanide to form thiocyanate as initially postulated in section 1.0. After a rapid initial reaction, a gradual decay occurs indicating the depletion of these compounds. QEMSCAN analysis confirmed the presence of pentlandite, chalcopyrite, pyrrhotite, pyrite and molybdenite as the main sulphide compounds in the ore residues after bioleaching, with molybdenite accounting for most of the residual sulphur. Although not detected by QEMSCAN it is still suspected that polysulphides and polythionates, resulting from incomplete biooxidation of sulphur, are the main group of sulphur species that are responsible for the initial high levels of thiocyanate in the effluent. The sulphides present in the bioleach residual ore, such as chalcopyrite are known to react with cyanide but at a relatively slower rate.

Although the percentage conversion is low overall, the levels of thiocyanate in $\mathrm{mg} / \mathrm{L}$ are still high, exceeding the limits for discharge to municipal sewers or drinking water supply (Nsimba, 2009; Stander et al., 1970). Thus the levels in the effluent (Figure 8) need to be adequately treated. It is worth noting that in the coarse ore leach the amount of sulphur oxidised was $75 \%$ of the starting total as compared to $44 \%$ in the first phase of the study where concentrate was leached. In making this comparison the total sulphur before leaching was quantified in both cases and found to be similar (32-35g per sample). This proves the second hypothesis that the longer leaching time in the coarse ore leach would result in higher sulphur oxidation. However this is still not adequate enough for the present application. A potential route to explore, as reported by Aswegen et al. (2007), is the use of microorganisms that oxidise only sulphur in 
addition to the current species of Metallosphaera hakonensis in the bioleach stage. This may help to oxidise more of the remaining sulphur species in the ore further minimising sulphur compounds that are migrating to the cyanide leach.

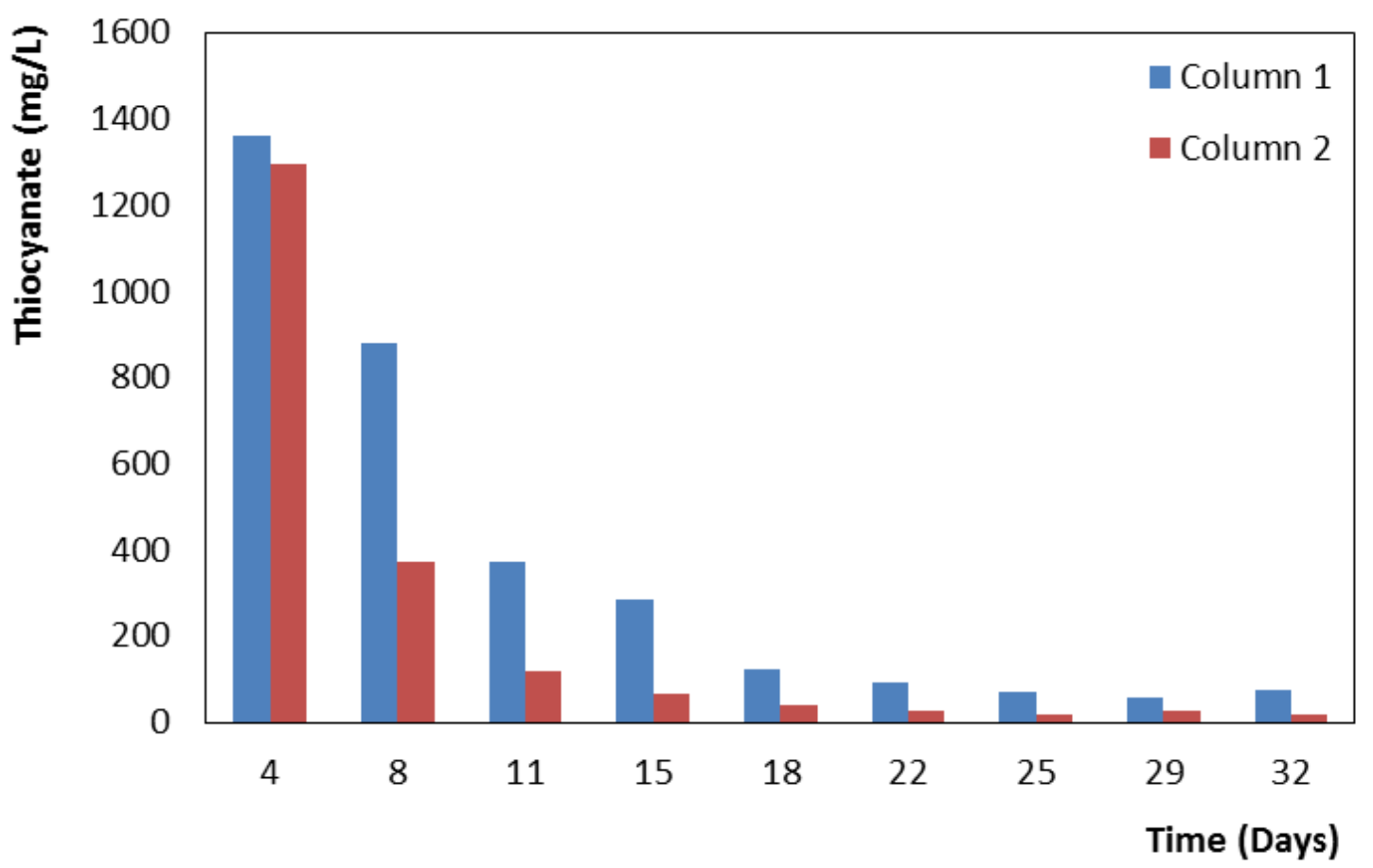

Figure 8: Thiocyanate in cyanide effluent solution.

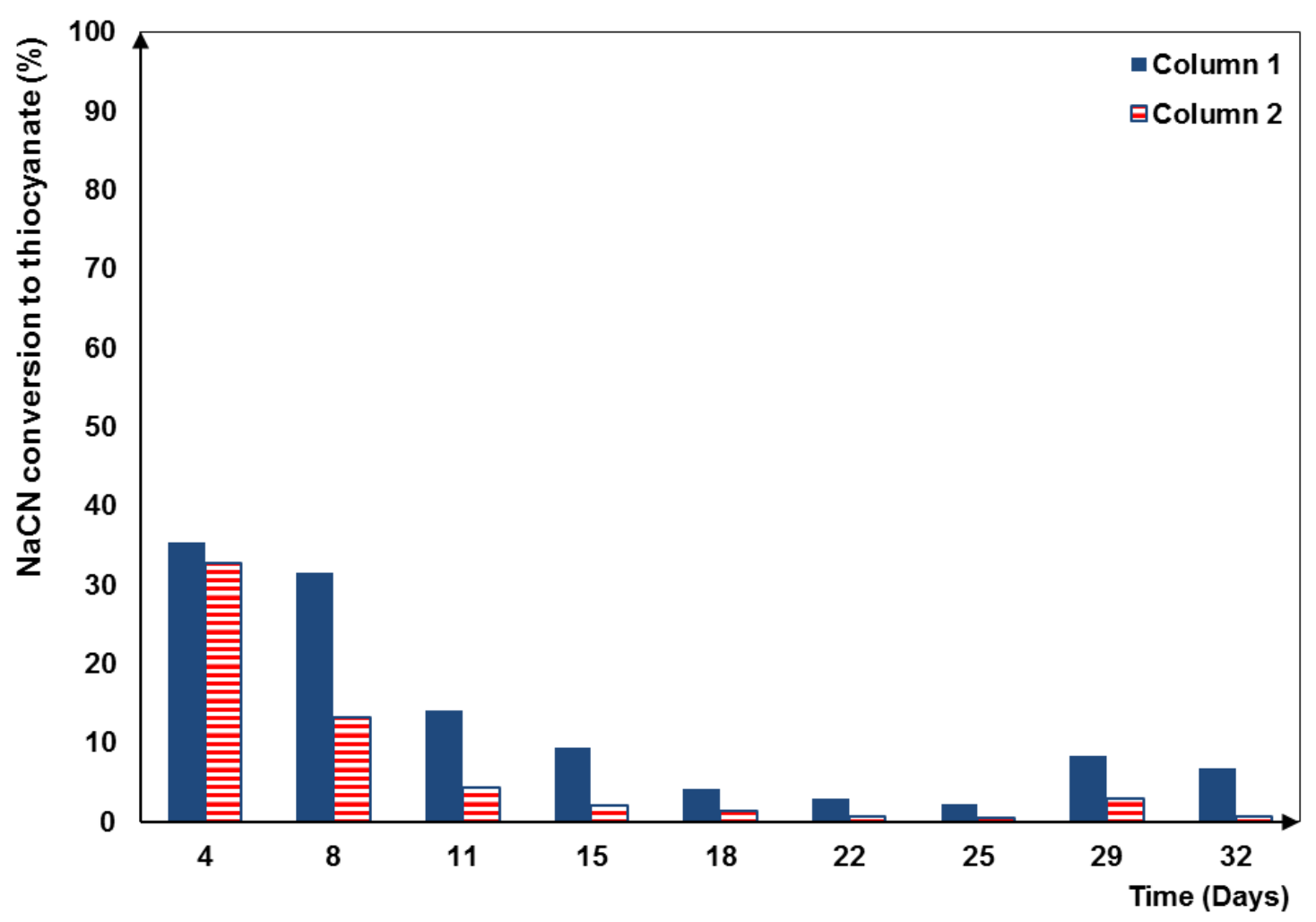

Figure 9: Percentage conversion of $\mathrm{NaCN}$ to thiocyanate. 


\subsection{Conclusion}

A novel sequential heap leach process, consisting of a first stage bioleach followed by a cyanide leach step is a potential alternative route to process Platreef ore directly by circumventing the energy intensive steps of milling, floating, smelting and pressure leaching. The extractions of BMs and PGMs achieved in this study, albeit comparatively low, may be economically viable considering that a coarse ore heap leach would offer substantial savings in capital and operating costs by eliminating the above mentioned process steps. The extractions for all the target metals achieved for the $-6 \mathrm{~mm}+1 \mathrm{~mm}$ were higher than those achieved for the $-25 \mathrm{~mm}+1 \mathrm{~mm}$ size fraction on average by $11 \%$. Further work must be conducted in investigating methods to increase the rate of Pt leaching from sperrylite, reducing the cyanide consumption levels and the levels of thiocyanate in the effluent from the cyanide heap leach.

\section{Acknowledgements}

The authors would like to thank Lonmin Plc for their financial support and permission to publish results. We would also like to acknowledge the support of the staff and students of the Centre of Bioprocess Engineering Research at the University of Cape Town.

\section{References}

Aswegen, P.C., Van Niekerk, J., Olivier, W. 2007. The BIOX ${ }^{\mathrm{TM}}$ process for treatment of refractory gold concentrates", in Rawlings, D.E., Johnson, D.B. (Eds.) 2007. "Biomining”, Springer-Verlag, Berlin, Heidelberg.

Bushell, C.J. 2006. "PGM grains detected by MLA in borehole core samples from Afriore", Mintek restricted report.

Chamberlain, P.G., Pojar, M.G. 1984, "Gold and silver leaching practices in the United States", Bureau of Mines Information Circular/1984, United States Department of the Interior IC 8969.

Eksteen, J.J., Mwase, J.M., Petersen, J.P. 2012. "Energy efficient recovery of precious metals and base metals", International Publication Number WO 2012/114165 A1, 30 August 2012.

Gupta, C.K., Mukherjee, T.K. 1990, "Hydrometallurgy in Extraction Processes Volume I", CRC Press, Boston.

Jergensen, G.V. (editor). 1999. "Copper leaching, solvent extraction, and electrowinning technology", Society for Mining, Metallurgy, and Exploration, Inc. USA

Kappes, D.W. 2002. "Precious metal heap leach design and practice", in Mular, A.L., Halbe, D.N., Barratt, D.J. (Eds.) 2002. "Minerals Processing Plant design, Practice, and ControlProceedings”, vol. 2, Society for Mining, Metallurgy, and Exploration, Inc. (SME).

Liebenberg, C.J., Dorfling, C., Akdogan, G., Bradshaw, S.M., Eksteen, J.J. 2013. "The recovery of copper from pregnant sulphuric acid bioleach solution with developmental resin Dow XUS43605", The Journal of the Southern African Institute of Mining and Metallurgy, vol. 113, no. 5, pp 389-397. 
Lien, L. 2008, “H W Process technologies' Engineered Membrane Separation ${ }^{\circledR}\left(\mathrm{EMS}^{\circledR}\right)$ systems for hydrometallurgical applications", Proceedings for Hydrometallurgy 2008-6th International Symposium, Society of Mining, Metallurgy and Exploration , 17-20 August, J W Marriot Desert Ridge Resort, Phoenix, Arizona.

Luthy, R.G., Bruce, S.G. 1979. "Kinetics of reactions of cyanide and reduced sulphur species in aqueous solution", Environmental Science and Technology, vol. 13, no. 12, pp 1481-1487.

Marsden, J., House, I. 2006, "The Chemistry of Gold Extraction", Society of Mining, Metallurgy and Exploration, Second Edition, Colorado, USA

Miller, P., Brown, A. 2005. "Bacterial oxidation of refractory gold concentrates", in Adams, M.D. (Ed). 2005. "Advances in Gold Ore Processing", Developments in Mineral Processing 15, Elsevier, Mutis Liber Pty Ltd., Guildford, Western Australia.

Mintek. n.d. CYNOPROBE: Online, in Process Cyanide Analysis, Retrieved July 2012 from: http://www.mintek.co.za/wp-content/uploads/2011/09/Cynoprobe-Brochure_en.pdf

Mogosetsi, D. 2006. "Comminution and flotation test work on ZF24 sample from the Akanani deposit”, Mintek restricted report 4484.

Mwase, J.M., Petersen, J., Eksteen, J.J. 2012a. "Assessing a two-stage heap leaching process for Platreef flotation concentrate", Hydrometallurgy, 129-130, 74-81.

Mwase, J.M., Petersen, J., Eksteen, J.J. 2012b. "A conceptual flowsheet for heap leaching platinum group metals (PGMs) from a low-grade ore concentrate", Hydrometallurgy, 111-112, 129-135.

Neale, J. 2012. "The application of bioleaching to base metals in Southern Africa: Prospects and opportunities", Bio-mining \& Acid Rock Drainage in S.A. seminar, University of Cape Town, Cape Town, 23 November.

Newell, A.J.H. 2008. "The processing of platinum group metals (PGMs)-Part 1", Pincock Perspectives, Consultants for mining and financial solutions, Issue no. 89-March 2008, Retrieved 12 February 2010 From http://pincock.com/perspectives/Issue89-PGM-ProcessingPart1.pdf

Nsimba, E.B. 2009. "Cyanide and cyanide complexes in the gold-mine polluted land in the East and Central Rand Goldfields, South Africa", MSc dissertation, University of Witwatersrand, Johannesburg, South Africa.

Plumb, J.J., Muddle, R., Franzmann, P.D. 2008. "Effects of pH on rates of iron and sulphur oxidation by bioleaching organisms", Minerals Engineering, vol. 21, issue 1, pp 76-82.

Pradhan, N., Nathsarma, K.C., Srinivasa Rao, K., Sukla, L.B., Mishra, B.K. 2008. "Heap bioleaching of chalcopyrite: A review", Minerals Engineering 21, pp 355-365.

Ream, B.P., Schlitt, W.J., 1997. 'Kennecott's Bingham Canyon heap leach program, part 1: the test heap and SX-EW pilot plant”, In: ALTA, Copper Hydrometallurgy Forum, Brisbane, Australia. 
Riekkola-Vanhanen, M. 2010. "Production Technologies: Talvivaara Mining Company Plc", Talvivaara Technical Seminar May 2010 presentation.

Roxburgh, B. 2011. "Exeter reports progress on the Caspiche stand-alone oxide pre-feasibility study", $\quad$ Retrieved October 2012 from http://www.exeterresource.com/pdf/2011_news/Exeter_news_110315.pdf

Saari, P., Riekkola-Vanhanen, M. 2011. "Talvivaara bio-heap leaching process", The Southern Africa Institute of Mining and Metallurgy, International Conference, Percolation leaching: The status globally and in southern Africa, Symposium Series S69, pp. 145-164, 7-9 November 2011.

Schay, S. 2009. "Drill core characterization and flotation test work on 13 drill cores from the Akanani depost", Mintek external report 5392.

Schoeman, E., Bradshaw, S.M., Akdogan, G., Eksteen, J.J. 2012. "The recovery of platinum, palladium and gold from heap solution with use of ion exchange resins", Proceedings of the $5^{\text {th }}$ International Platinum Conference, $18-20^{\text {th }}$ September, Sun City, South Africa, Vol. II, pp 729742.

Schouwstra, R., P.; Kinloch, E., D. 2000, "A short geological review of the Bushveld Complex", Platinum Metals Review, vol. 44, issue 1, pp 33-39.

Seymour, R.J., O'Farrelly, J.I. "Platinum Group Metals", Kirk-Othmer Encyclopedia of Chemical Technology-Online. Published online: 13 July, 2001, Retrieved 22 September

2007 From http://www.mrw.interscience.wiley.com/emrw/97804712389 66/kirk/article/platseym.a01/current/pdf.

Shackleton, N.J., Malysiak, V., O'Connor, C.T. 2007a. "Surface characteristics and flotation behavior of platinum and palladium arsenides", International Journal of Mineral Processing 85, $25-40$.

Shackleton, N.J., Malysiak, V., O'Connor, C.T. 2007b. "Surface characteristics and flotation behavior of platinum and palladium tellurides", Minerals Engineering 20, 1232-1245.

Sharma, V.K. 2003. "Destruction of cyanide and thiocyanate by ferrate[Iron(IV)]", The European Journal of Mineral Processing and Environmental Protection, Vol.3, No.3, 13030868, pp. 301-308.

Snyders, C.A., Mpinga, C.N., Bradshaw, S.M., Akdogan, G., Eksteen, J.J. 2013. "The application of activated carbon for the adsorption and elution of platinum group metals from dilute cyanide solutions", The Journal of the Southern African Institute of Mining and Metallurgy, vol. 113, no. 5, pp 381-388.

Stander, G.J., Henzen, M.R., Funke, J.R. 1970. "The disposal of polluted effluents from Mining, Metallurgical and Metal Finishing Industries, their effects on receiving water and remedial measures", Journal of the South African Institute of Mining and Metallurgy, December 1970, 95-103. 
Stewart, M., Kappes, D. 2011. "SART for copper control in cyanide heap leaching", The Southern Africa Institute of Mining and Metallurgy, International Conference, Percolation leaching: The status globally and in southern Africa, Symposium Series S69, pp145-164, 7-9 November, Misty Hills, Muldersdrift, South Africa.

Tempel, K., 2003. "Commercial biooxidation challenges at Newmont'sNevada operations", In: 2003 SME Annual Meeting, Preprint 03-067, Soc Mining, Metallurgy and Exploration, Littleton, Colo.

van Rensberg, S.J., Lotz, P.W. 2010. "Kinetic cyanide and arsenic data generation during gold leach tests by MINTEK Advanced Leach Facility", presented at the Precious Metal 10 conference, Falmouth, UK, 15-16 June.

van Zyl, D., Henderson, M., Cobb, B. 1990. "Economic aspects of pad construction costs on heap leach projects", International Journal of Mining and Geological Engineering 8, 275-286. 